This item was submitted to Loughborough's Research Repository by the author.

Items in Figshare are protected by copyright, with all rights reserved, unless otherwise indicated.

\title{
Redesigning the concept of money: a service design perspective on complementary currency systems
}

PLEASE CITE THE PUBLISHED VERSION

https://doi.org/10.1386/dbs.3.1.21 1

\section{PUBLISHER}

(C) Intellect

VERSION

AM (Accepted Manuscript)

\section{PUBLISHER STATEMENT}

This work is made available according to the conditions of the Creative Commons Attribution-NonCommercialNoDerivatives 4.0 International (CC BY-NC-ND 4.0) licence. Full details of this licence are available at: https://creativecommons.org/licenses/by-nc-nd/4.0/

\section{LICENCE}

CC BY-NC-ND 4.0

\section{REPOSITORY RECORD}

Telalbasic, Ida. 2019. "Redesigning the Concept of Money: A Service Design Perspective on Complementary Currency Systems”. figshare. https://hdl.handle.net/2134/23907. 


\title{
Re-designing Money: A Service Design Perspective on Complementary Currency Systems
}

\begin{abstract}
The current failures in income distribution among communities, social entrepreneurs and start-up founders result from deficit of money for accessing goods and services. However, it is increasingly recognized that money has the potential to be re-designed in order to serve a different purpose and to adapt to the emerging paradigm of the collaborative economy. Within this context, this article presents a study aimed to explore complementary currency systems as resilient strategies. This is done by adopting a service design perspective to analyze case studies from developing and developed economies. Both contexts are investigated in order to identify whether the case studies are founded by individuals, communities or governments. Furthermore, organizational models, as well as the main motivations and conditions for the emergence of these alternative economic models, are examined. Moreover, the key drivers for creating complementary currency systems are highlighted. For instance, in the developing world, those systems stem from the need for establishing financial inclusion and building stronger trust and community ties. Instead, in developed economies, they rise in order to use existing local resources, foster individual empowerment, enhance collaboration with a community, as well as achieve economic benefit. Complementary currency systems are here proposed as a tool for linking unmet needs with unused resources. They also enable informal financial institutions contributing to behavioral change through meritocracy. Once those systems are designed as smallscale initiatives, prototyped and implemented in different communities, they have the potential to become effective strategies for subversion and intervention. The case studies show that equal participation and local empowerment can lead to proactive democratic models increasing economic stability. In conclusion, this article argues that service design, through systems of permanent or temporary access to credit, not only responds to contemporary socio-economic conditions, but also contributes to shape new ways of practicing democratized economics.
\end{abstract}

Keywords: Complementary currency systems; case study; developing and developed economies, service design, social innovation

\section{Introduction}

This article presents part of a doctoral research conducted in order to tackle the urgent consequences of the global socio-economic crisis. This downfall has created conditions of high unemployment and resulted in a deficit of cash flow for individuals and diverse communities. This has affected them by preventing operation and development of their businesses and offer of their skills and competences on the market. To address this problem, this research is positioned within three distinct yet complementary disciplines: economics, sociology and design. In particular, this research sets the stage for merging economics and service design in order to disrupt this issue, explore challenges as opportunities, and design resilient strategies for long-term resistance.

The overarching aim of this article is to explore how service design can play a leading role in economic transformations and contribute to resilient ways of practicing democratized economics. This is done by mapping existing alternative economic models in both developing and developed contexts in order to understand motivations for creating new currencies and injecting complementary capital across global locations.

Within the scope of this research, this article explores the strategic opportunities for currency innovation to be adopted in the emerging paradigm of the collaborative economy. Complementary currency systems are here proposed as alternative economic models that circulate in parallel to conventional money. This article presents six promising cases in order to demonstrate alternative monetary systems that can act as mechanisms for territorial and social cohesion. These cases are relevant in relation to the failures in income distribution and financial exclusion. This article will explore why complementary currencies can be conceived as a tool, strategy and framework for social innovation, leading to establishing new service systems that empower people, through the creation of new networks, increased social ties, as well as local knowledge and expertise. Finally, the potentials of design for creating strategies capable for addressing financial exclusion will be explored. From this 
perspective, design is considered as a facilitation mechanism for 'co-empowering' and transforming idle capacities of skilled individuals into social capital and collaboration opportunities.

\section{Principles of Currencies}

Addressing the consequences of current social transformations requires an understanding of the root causes of the ongoing socio-economic crisis. Compared to the pre-industrial and industrial periods, the post-industrial society is witnessing an increase in the speed of growth in terms of technology innovation and accessibility of information (Allen and Massey, 1988). However, at the same time, there is an occurrence of scarcity of resources that, due to economic busts, refers to the deficit of money as an essential tool in contemporary society for the provision of goods and services (Lietaer, 2001). Any deficit of money cripples an economy since the lack of circulation of goods and services blocks the economic ecosystem from operating and providing value within a physical or digital network. The notion of money or currency can be explained in a straightforward way, considering that we all use money, in one way or another. Therefore, the different types of currencies in use only refer to the diverse geographies, exchange rates and national policies that govern those monetary systems. However, we need to ask ourselves: "Where does money really come from and how is it created?" Most of us think that money is created by the government or the central bank or through printing machines or something else we cannot really decipher (Lietaer, 2001).

Lietaer \& Dunne (2013) explain that $90-95 \%$ of all our money is created from debt in the banking system. This means that every currency, for example EUR, is someone else's debt, be that government, corporate or private debt. The authors also explain that the reason why a national currency can be exclusively unique is because governments only accept that one currency to pay for taxes. If we look closer to these definitions, money is usually defined as a 'unit of account', 'medium of exchange' and/or 'store of value'. However, this is not what money is, but what money does (Lietaer et al., 2012). This distinction is also crucial for the purpose of presenting the following case studies that highlight the shifts in thinking from the primary function of money to a new value paradigm. The case studies aim to present concepts based on in-depth exploration of how money is perceived, what it really is and what it could potentially become. One definition of money is that: "Money is an agreement within a community (no matter what the scale) to use something (standardized) as a medium of exchange" (Lietaer \& Dunne, 2013, p.49). To elaborate on this, the authors argue that any 'agreement' in society that does not work in its present state has the potential to be changed. Therefore, the current monetary system, based on monopolistic currencies, illustrates today's problem of cash deficit and structural instability (due to numerous crashes), opening up the need for a currency innovation. Currencies, just like all other things, have the potential to be redesigned, in order to serve a different purpose and to adapt to an emerging economic paradigm we are witnessing today in the 'collaborative economy' (Botsman, 2010). Therefore, design has the power to grasp these socio-economic transformations and to propose new economic models based on complementary social currency systems.

\section{Complementary Currency Systems}

The current socio-economic transformations occurring today can be traced back to similar periods in economic history that reflected busts in the economy, and thus the lack of money in the system. Looking back to the midst of the Great Depression (1929), it is possible to identify a couple of currency schemes that laid foundations for a structural solution in those economic contractions. One of the most successful examples of complementary currency systems is the 'WIR Bank' in Switzerland. It prevented small-to-medium enterprises (SMEs) from going bankrupt by injecting additional capital (newly created complementary currency to run in parallel to the Swiss Franc) in order to keep money circulating in the economy through continued exchange of goods and services. "A complementary currency is an agreement to use something else than legal tender (i.e. national money) as a medium of exchange, with the purpose to link unmet needs with otherwise unused resources" (Lietaer and Hallsmith 2006, p.2). 
The previous example describes a structural solution, pointing to the fact that all monetary and financial crises have a structural cause. According to Lietaer (2001), complementary currencies should circulate in parallel to conventional money, in an economy where they can structurally diversify the medium of exchange. Kalinowski $(2011$, p.1) claims that, "Parallel currencies play a critical role in the current wave of social innovation. They can assume different forms - local currencies, time currencies, local exchange systems, inter-company credit systems...as mechanisms for territorial or social cohesion". There are many advantages of using complementary currency systems and we shall see those more clearly in the following case study analysis.

\section{Research Methodology}

As part of a PhD research project, the theoretical conceptual framework is based on three distinct, yet complementary disciplines: economics, sociology and design. Service design sets the disciplinary framework that aims to research the potentials of an emerging discipline, especially in terms of fostering collaborative participation and consumption towards design-driven innovation. The aim of the doctoral research is to explore how service design can have a leading role in economic transformations and contribute to new ways of practicing democratized economics. The main objective is to understand how service design contributes to the creation of resilient and democratized economic models that can act as a facilitation mechanism for co-empowering and transforming idle capacities of skilled individuals into social capital and collaboration opportunities. In order to achieve this aim, it is necessary to map existing alternative economic models as sources of inspiration for designing a new economic landscape.

The research questions guiding this research are:

What type of collaboration models can service design create in the private sphere to provide job opportunities, knowledge exchange and business development in times of economic transformations?

How can a complementary enabling exchange mechanism be co-designed to support the transformation of idle capacity between highly skilled individuals into collaboration opportunities through the means of a new currency?

The case study research strategy was deployed in order to explore the different kinds of exchange models that have been initiated by diverse determinants in both developing and developed economic contexts.

\section{Case Study Overview}

The six case studies presented in this paper are part of a wider collection of twenty-four global complementary currency systems. The case study analysis is divided into two main sections according to the economic development of economies where those case studies have emerged: developing and developed economies. This is done in order to highlight the differences between the two contexts; to identify the initiation determinants (founded by individuals; communities; or governments); as well as the main motivations and conditions that have triggered these alternative economic models to exist in the first place. The sample strategy includes the initiation determinants, location and date of operation, the identification of providers and promoters, and finally the service typologies. The service typologies analyze each case study from the perspective of a service model and looks at the types of system format, operational structure, interaction patterns, and the sector of operation. The service typologies refer to service: System; Structure; Interaction; and Sector (Fig. 1). 


\begin{tabular}{|c|c|}
\hline SYSTEM & \\
\hline \hline OPEN & Can be replicated and scaled in other locations \\
\hline \hline CLOSED & Targets a bounded and specific geographic area \\
\hline
\end{tabular}

\begin{tabular}{|c|c|}
\hline CENTRALIZED & The currency transactions are distributed and/or monitored by a central source \\
\hline DECENTRALIZED & Ownership, management and responsibility is shared among community mem \\
\hline
\end{tabular}

\section{INTERACTION}

\begin{tabular}{|c|l|}
\hline P2P & Peer-to-peer transactions \\
\hline \hline B2C & Business transactions with a customer and vice versa \\
\hline \hline B2B & Business-to-business transactions \\
\hline
\end{tabular}

\section{SECTOR}

\begin{tabular}{|c|l|l|}
\hline PUBLIC & Operates in the public sphere for common good and is governed by non for-profit entities \\
\hline \hline PRIVATE & Operates within private entities and governed in a for-profit fashion \\
\hline \hline THIRD & Includes both the voluntary sector and public-private partnerships \\
\hline
\end{tabular}

Figure 1. Service Typologies

The complete collection of case studies includes the following best practices from both developing economies (Fig. 2), and developed economies (Fig. 3), clustered according to the initiation determinant and also according to the service typologies previously described.

a) Developing Economies: Grameen Bank (Initiated by Individual), Chit Funds, Susu Collectors, Palmas Bank, Eco Pesa, Credito (Initiated by Communities), Doras and Torekes (Initiated by Government).

\section{DEVELOPING ECONOMIES}

\begin{tabular}{|c|c|c|c|c|}
\hline CASE STUDY & SYSTEM & STRUCTURE & INTERACTION & SECTOR \\
\hline \multicolumn{5}{|l|}{ Initiated by Individual } \\
\hline GRAMEEN BANK & OPEN & DECENTRALIZED & P2P & PUBLIC \\
\hline \multicolumn{5}{|l|}{ Initiated by community } \\
\hline CHIT FUNDS & OPEN & DECENTRALIZED & P2P & PUBLIC \\
\hline SUSU COLLECTORS & OPEN & DECENTRALIZED & P2P & PRIVATE \\
\hline PALMAS BANK & OPEN & DECENTRALIZED & P2P & PUBLIC \\
\hline ECO-PESA & CLOSED & CENTRALIZED & B2B & PRIVATE \\
\hline CREDITO & \multirow[t]{2}{*}{ OPEN } & \multirow[t]{2}{*}{ CENTRALIZED } & \multirow[t]{2}{*}{ P2P } & \multirow[t]{2}{*}{ PUBLIC } \\
\hline Initated by Government & & & & \\
\hline DORAS & OPEN & DECENTRALIZED & $P_{2} \mathrm{P}$ & PUBLIC \\
\hline TOREKES & CLOSED & CENTRALIZED & $\mathrm{B} 2 \mathrm{C}$ & PUBLIC \\
\hline
\end{tabular}

b) Developed Economies: Stamp Scripts, Wir Bank, Sol Project, Wat System, Ven, Bitcoin, Brixton Pound, Sardex (Initiated by Individuals), Jak Medlems Bank, Fureai Kippu, Spice Time Bank, Bristol Pound, LETS (Initiated by Communities), Guernsey Market House Notes, SoNantes and Makkie (Initiated by Government). 


\begin{tabular}{|c|c|c|c|c|}
\hline CASE STUDY & SYSTEM & STRUCTURE & INTERACTION & SECTOR \\
\hline \multicolumn{5}{|l|}{ Initlated by Individual } \\
\hline STAMP SCRIPT & OPEN & DECENTRALZZED & 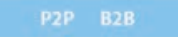 & THIRD \\
\hline WIR BANK & CLOSED & CENTRALIZED & $B 28$ & PRIVATE \\
\hline SOLPROJECT & OPEN & CENTRALIZED & $B 2 C \quad 828$ & THIRD \\
\hline WAT SYSTEM & CLOSED & DECENTRALIZED & P2P B2B & PRIVATE \\
\hline VEN & OPEN & CENTRALIZED & P2P & PRIVATE \\
\hline BITCOIN & OPEN & DECENTRALIZED & $P 2 P \quad B 2 C \quad B 2 B$ & PRIVATE \\
\hline BRIXTON POUND & CLOSED & CENTRALIZED & $B 28$ & PRIVATE \\
\hline SARDEX & CLOSED & CENTRALIZED & \multirow[t]{2}{*}{ B2B } & PRIVATE \\
\hline \multicolumn{4}{|l|}{ Initiated by Community } & \\
\hline JAK MEMBERS BANK & OPEN & CENTRALIZED & P2P & PRIVATE \\
\hline FUREAI KIPPU & OPEN & DECENTRALIZED & P2P & PUBLIC \\
\hline SPICE TIME BANK & OPEN & CENTRALIZED & P2P & THIRD \\
\hline BRISTOL POUND & CLOSED & CENTRALIZED & $B 2 C \quad B 2 B$ & PUBLIC \\
\hline LETS & CLOSED & CENTRALIZED & 828 & THIRD \\
\hline \multicolumn{5}{|l|}{ Initiated by Government } \\
\hline GUERNSEY NOTES & OPEN & CENTRALIZED & P2P & PUBLIC \\
\hline SONANTES & OPEN & CENTRALIZED & $\mathrm{B} 2 \mathrm{C} \quad \mathrm{B} 2 \mathrm{~B}$ & PUBLIC \\
\hline MAKKIE & CLOSED & CENTRALIZED & $P 2 C \quad P B 2 C$ & PUBUIC \\
\hline
\end{tabular}

Figure 3. Developed Economies

\section{Developing Economies}

If the term 'developing' is defined with inverting criteria that defines a developed country, such as: contexts where people have less education and income, implying a certain kind of inferiority (O'Sullivan and Sheffrin, 2003), then there is a forced need to take a closer look at these realities and identify the ways in which these underdeveloped environments have given rise to some unique forms of innovation. The developing status with regards to developing economies manifests diverse strengths through economic empowerment of the poor through permanent access to credit. These forms can be closely observed through emerging practices that demonstrate a new set of existing behaviours as a way to address emerging social and economic problems. "It is these types of selforganisations, created out of necessity, within local communities and with the help of governing bodies in some cases, as assets, provide a rich source of inspiring solutions" (Author, 2016, p. 65). We will now look, in more details, at the cases of Grameen (Initiated by Individuals); Eco Pesa (Initiated by Community); and Torekes (Initiated by Government).

\section{a) Complementary Currency System Initiated by an Individual}

One well-known practice is the Grameen Bank (1983) in Bangladesh that demonstrates the potential of a microfinance contemporary banking phenomenon. It is founded by Muhammad Yunus who received the Nobel Peace prize for his work in 2006. The philosophy behind the project is that small loans provide both the means and the incentive for individuals in poverty to start small enterprises or agricultural initiatives, enabling them to better their financial position in a permanent way (Yunus, 2002). In the Grameen bank, each borrower belongs to a small group. Each member is responsible for repaying only his/her own loan; he/she is not responsible for the loans of the other members if they default, but at the same time no further credit will be extended to the group if any of the members is in default. This means that social pressure from within the group is the major source of securing repayment and members will often help each other towards that goal. This has been termed as solidarity lending (Abhas, 2000). To ensure repayment, the bank uses a system of 'solidarity groups'. These small informal groups apply together for loans and its members act as co-guarantors of repayment and support one another's efforts as economic self-advancement (Ghatak and Guinnane, 1999). 


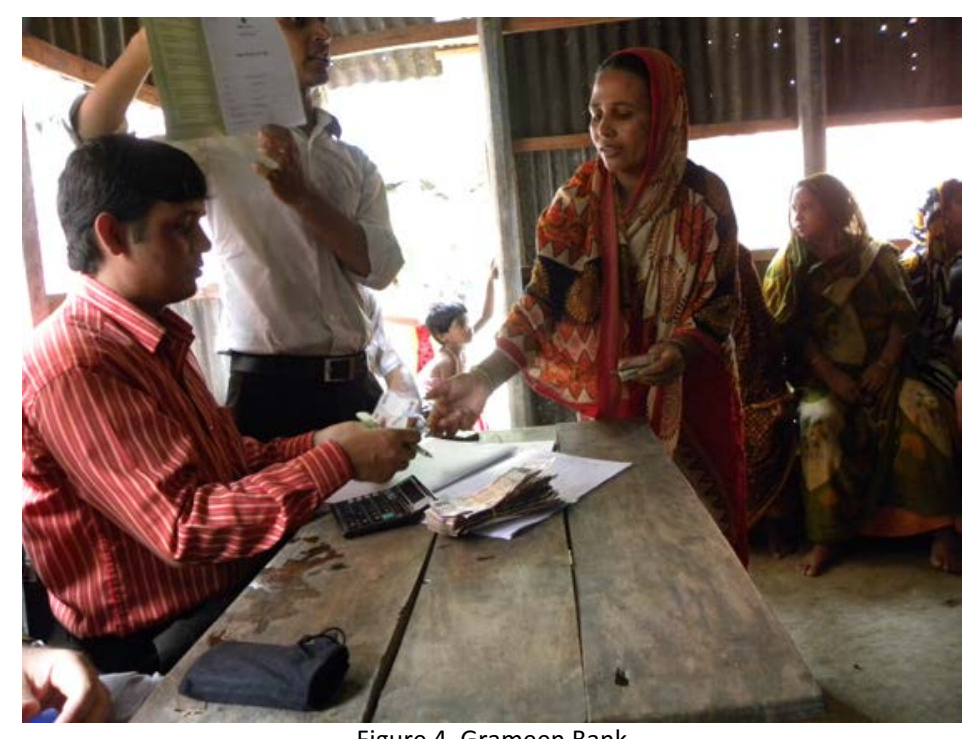

Figure 4. Grameen Bank

All contracts within Grameen Bank are based on trust, as opposed to legal documents. “Group lending - or the joint liability contract-is the most celebrated lending innovation by the Grameen Bank" (Sengupta and Aubuchon, 2008, p.12). The success of microfinance lies in "leveraging modest subsidies to build financial institutions and industries that give millions of poor families more control over their finance" (Roodman, 2011. p.6). Roodman (2011) also adds that in order to help people manage the uncertainties of being poor, it is important to focus on mass-producing services that enable this. In this way, not only is capital injected to a huge number of people in the hope of launching entrepreneurs, but conditions are created to support them through service systems. It is important to note the difference between microcredit and microfinance (Armendáriz de Aghion and Morduch, 2000) even though the two are interrelated. Microcredit refers to the loan that is provided to members, while microfinance provides "borrowers with financial services, such as savings institutions and insurance policies" (Sengupta and Aubuchon, 2008, p.10).

In terms of service typologies, the Grameen Bank case shows an open system format that has the potential to implement microcredit and microfinance in other contexts. The service system operational structure has a decentralized ownership and management style where all community members equally share the responsibility. The interaction type is between individuals who work as small-scale entrepreneurs. Since a small percentage of ownership is helped by the government of Bangladesh, the sector is public and the bank itself is owned by its borrowers.

\section{b) Complementary Currency System Initiated by Communities}

The aim of the Eco-Pesa programme, established in Kenya in 2013 and promoted by the Eco-Business network, was "to promote and facilitate environmental social service work and economic development in impoverished informal settlements (slums) through the innovative use of a complementary currency" (Ruddick, 2011, p.1). In these areas, unemployment can reach $80 \%$ and the lack of a local currency prevents neighbours from bartering with goods and services they might be able to offer. However, this lack of money causes the local residents to find other ways for them to barter, using an alternative means. Eco-Pesa is a unit of credit within a 'mutual-credit-clearing' (Greco, 2009) system that provides a means of payment that is complementary to official money and can be converted to the local shilling currency as well. Credits are issued in the form of papervouchers that can pass from hand to hand as payment for goods and services. These vouchers are not meant to replace or be legal tender in any way, but rather represent the goods and services of the business network (in the video Bangla-Pesa - Empowering a Grassroots Economy, 2013). By definition, "Eco-Pesa can be seen as a development effort to empower impoverished people to increase their incomes in a manner that provides for public health and environmental conservation" (Ruddick, 2011, p.2). 


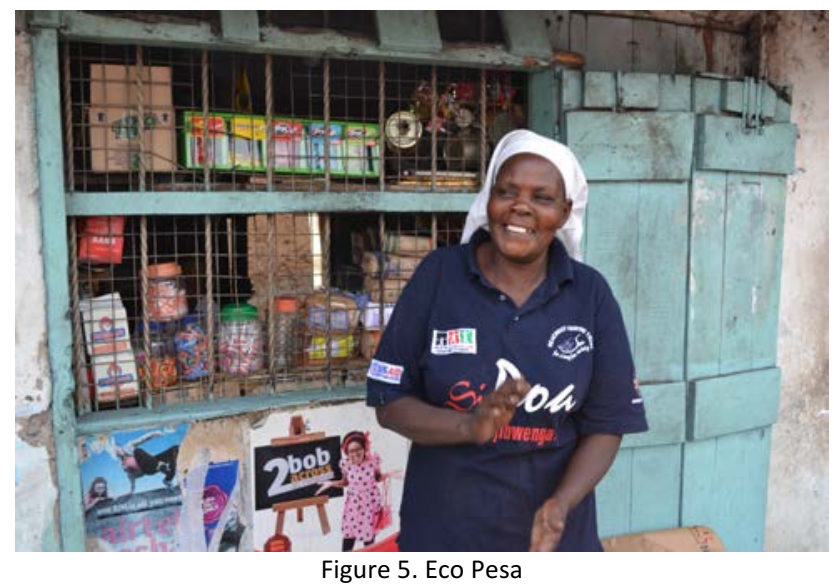

In the context of sever poverty and lack of infrastructure, the Eco-Pesa programme assists local businesses and helps clean up and protect the local environment in several neighbouring informal settlements (Ruddick and Mariani, 2013). The complete absence of waste-management creates serious health risks for residents. Local residents earn Eco-Pesa currency by cleaning up trash in public areas. Local youths are also paid in Eco-Pesa for constructing and tending to seedbeds where trees are grown as a strategy towards combating the deforestation that has occurred in the area (Ruddick, 2011). In this way, "currency networks can connect businesses with new customers sharing values such as reducing carbon footprints (...)" (in the report People powered money, 2015). Complementary currencies have "the amazing ability to refocus a local economy, and to harmonize, by design, the relationship between a cash economy and the environment" (Ruddick, 2011. pg.2). Through the network, these actors also have access to small loans that in turn encourage trade to stay in the neighborhood. This provides an additional means of injecting a currency into the local economy by allowing residents to earn it by caring for and sustaining the local environment (Ruddick, 2011). It is evident that community currencies enable community involvement and make the local governing of these projects more sustainable than regular currencies. In addition, the money itself is designed by local youths, selected by village elders, further encouraging the community's ownership of the economy (Ruddick and Mariani, 2013). The fundamental driver of this economic stability and increase in trade is due to the members' ability to trade their excess capacity (Ruddick, Richards and Bendell, 2015).

In terms of service typologies, the Eco Pesa case shows it is a closed mutual credit clearing system that only targets community members of the Eco-Business network. It has a centralized operation service structure where currency transaction is distributed and monitored by a central source. The interaction typology considers business-to-business transactions and is privately owned by its promoting business network.

\section{c) Complementary Currency System Initiated by Government}

Torekes is an experimental project, started in 2011, by 'Netwerk Vlaanderen vzw', introducing a social complementary currency 'Toreke' in Ghent, Blegium. The case of Torekes is presented here, not because Belgium falls under a developing country category but because the currency was initiated in Rabot, one of the poorest communities in the entire region. In the video Money Diversity (2001), Lietaer explains there is a large immigrant population mostly unemployed and living in densely populated low cost apartments. These inhabitants wish for some gardening space in the area to use small parts of the land for growing vegetables (McKinnon and Alston, 2016). Since the city owns abandoned land in the neighbourhood, the local government decided to rent out pieces of land to these foreign residents as gardening plots and these small rents were to be paid for in Torekes currency. The cost of four meter ${ }^{2}$ is 150 Torekes that has become a "newly introduced local cooperative currency" (Lietaer and Dunne, 2013, p.152) and the project is supported by the Flemish Ministry for Social Economy. 
Torekes currency can be earned by planting window boxes on the facades, using green power in the households and collecting litter in the local area. "Participating shops can either use Torekes for their own participation in local activities or simply get them reimbursed for euros at the city office" (Lietaer and Dunne, 2013, p.152). They can also be spent on bus passes, cinema tickets, low energy bulbs, fresh vegetables and products from participating retailers. The exchange rate for 1 EUR is 10 Torekes (Torekes, 2010).

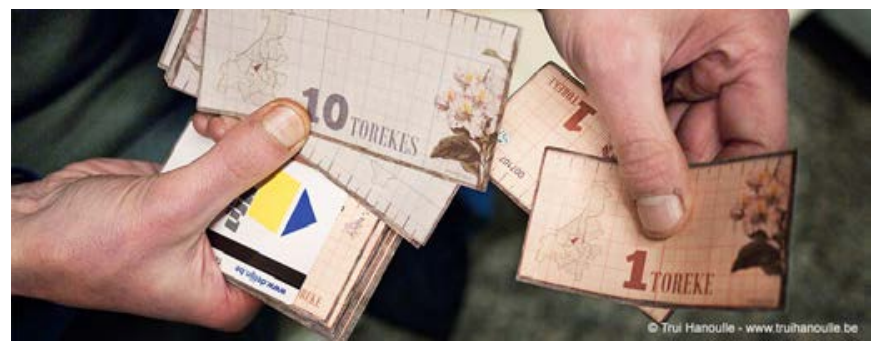

Figure 6. Torekes Currency

There is also a local Toreke café that has about ten staff who might otherwise be unable to find a job. They serve up healthy meals, using vegetables grown on the rented partitions and meat from a local butcher. This is an efficient business model that demonstrates the cooperation between local stakeholders. It offers a much-needed spot for local residents to get together but also delivers meals by bike to elderly citizens who cannot get there easily. As well as making payments in Torekes, the café provides discounted meals to those in financial difficulty (on Torekes website Workflow: Torekes explained, 2010).

In terms of service typologies, the Torekes case shows it is an open system, targeted to this geographic area, especially in terms of the land rented to the immigrant population and also the other stakeholders who accept this currency. It has a centralized operation service structure between businesses and the citizens, i.e. business-to-customer interaction pattern, that enables Torekes to be earned and spent locally. This currency belongs to the local government (public sector) who supports the project. This experiment has shown a very positive and broad social impact with three times more activities produced with the same euro budget (Lietaer and Dunne, 2013). The Torekes top-down model is an example of how "planners decide everything is challenged by a bottom-up approach that stresses the practical value of public places for its inhabitants" (McKinnon and Alston, 2016, p.88).

\section{Reflections on Cases from Developing Economies}

Next, we will reflect on the three cases from developing economies previously presented and see what common features emerge (or in the case of Torekes from Belgium, from a developing neighbourhood). The case of Grameen Bank in Bangladesh, initiated by an individual, shows how social pressure plays a crucial role in securing repayments in the way the behaviour of one individual can be reflected on the status of his/her family. This pressure to behave correctly shows how informal financial institutions can easily contribute to the creation of trust within these networks. The established social pressures within the group make sure that the necessary repayments are secure and in this way solidarity is promoted and kept long-term. This system of social discrediting is apparent in the case of Grameen Bank where the role of community members who primarily own and run the bank (made up of both borrowers and lenders) creates a certain kind of 'provider-user reciprocity' (Author, 2016, p. 124).

However, there is a difference between social shaming (described above) and the social networks that provide an additional guarantee within the alternative economic systems. The second scheme is obvious in other cases, not presented in this paper, where low-income citizens are not required to register or provide documents but neighbours give a guarantee for the person receiving the credit. This model between individuals, also evident in the case of Eco Pesa, acts as a community validation that additionally increases the collaborative nature of the exchange interactions. Eco Pesa operates with positive credit for the businesses, facilitating immediate spending and therefore a simple 
adaptation of new currency for business-to-business transactions. The mechanism of guaranteeing membership encourages both responsibility and trust within the network.

The Torekes case study, initiated by the government, shows the links with local authorities and the will to implement an alternative credit system into the existing social order and thus support the development of a social economy. The large public space has become a public garden for "micro practices of solidarity among people in vulnerable social positions" (McKinnon and Alston, 2016, p.85). To this end, this also demonstrates the aim of successfully giving money back its original function of being a means and not an end in itself. Since it is all about small actions, the complementary currency method brings behavioral changes through reward. Many residents can participate in the newly created financial ecosystem, including those who are strapped for cash and often fall to the sidelines in other premium systems.

In conclusion, it becomes evident that complementary currency systems, in developing economies, are created for the purpose of establishing financial inclusion, and building stronger community ties and trust.

\section{Developed Economies}

Since 1970, the International Monetary Fund defined hundreds of bank crashes and monetary collapses that clearly demonstrate our instable economic systems (Lietaer, et al., 2010). New forms of innovation can be closely observed through emerging practices that demonstrate a new set of existing behaviours as a way to address emerging social and economic problems. We will now look in more details, at the cases of Wir Bank (Initiated by Individuals); Bristol Pound (Initiated by Community); and Makkie (Initiated by Government).

\section{a) Complementary Currency System Initiated by an Individual}

WIR is the most famous example of a mutual credit clearing system (Ruddick and Mariani, 2013) that connects businesses in an exchange network. It supports small to medium enterprises on the territory of Switzerland, providing the ability to pay short-term obligations in times of economic crisis and business promotion. Wir is founded by Werner Zimmerman and Paul Enz who are supporters of 'free money' theorist Silvio Gesell (Wuethrich, 2004). WIR stands for both WIR, the German word for "we", and 'Wirtschaftsring', which means "economic ring/circle" and its original name was the Economic Circle Cooperative (Kennedy, et al., 2012). The WIR is a "centralized credit system for multilateral exchange, however, with no physical currency" (Stodder, 2009, p.79). This long-lasting cooperative began in Switzerland in 1934, a period of global economic instability and currency shortages in the country, between the two world wars. The circle has 80.000 members from all over the country, operating in four languages. It is the oldest continuous system in the modern Western world, functioning for more than 60 years (Kennedy et al., 2012). The demand for WIR increases in periods of crisis, when regular banks reduce lending, and decreases in periods of growth when commercial banks are lending the national currency again (Lietaer and Dunne, 2013).

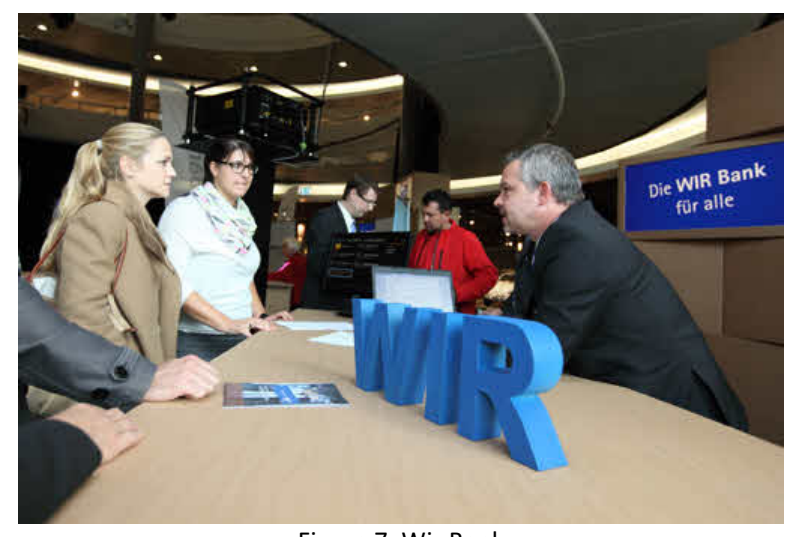

Figure 7. Wir Bank 
The currency is issued by a "cooperative bank and is backed only by the mutual agreement of its members to accept it for payment" (Eisenstein, 2011, p. 212). The value of WIR is worth the same as a Swiss franc, i.e., 1 WIR = 1 Swiss franc, and WIR cannot be exchanged for Francs but they can only be spent as WIR currency (Lietaer, 2001). Members pay a small fee to join cooperative and start trading with each other, each trade being recorded with a central book keeping authority. No money actually changes hands since WIR money is created in the moment of exchange and there are limits to positive/negative credit balance that each member can have on their account (Wir Magazine, 1994). To obtain WIR credits, members can either sell goods or services to someone else in the circle, or obtain them directly from the coordinating center (Stodder, 2009).

In this way WIR is a "hybrid of mutual credit model (trading occurs by selling goods directly) and fiat currency $^{1}$ (whenever a loan is made from the center)" (Lietaer, 2001, p.169). Whenever a member reimburses a loan to the center, WIR credits are automatically removed from circulation. The WIR system is quite flexible in terms of the total money in circulation, since the "individual's debit position is set by overdraft limits, the absolute value of all credits and debits is determined only by economic need" (Stodder, 2009, p.82). Positive credit balances do not earn interest since there is no benefit to holding on to credit. Many trades occur in a mix of Francs and WIR currency (membership rules are that every trade is conducted with at least one third in WIR). Members who join as private individuals can keep balances in both the national currency (Swiss Francs) and in WIR credits (Studer, 1998). Members can borrow Swiss Francs after having traded in WIR credits for a while, at interest rates much lower than regular bank rates (Lietaer, 2001). The offers have expanded to mortgages and business loans. Non-members can also make WIR exchanges, but have to pay a slightly higher transaction fee (Studer, 1998).

In terms of service typologies, the Wir Bank case shows a closed system format. However, WIR demonstrates that exchanges that build communities without money are possible even on a large scale and can be lasting entities. The service operational structure is centralized and focused on business-to-business transactions, demonstrating how such an economic circle actually enables small businesses to overcome economic downturns, making the hardship of crises manageable and creating more economic stability for the entire country. It also illustrates how a non-profit institution can provide a reliable fallback during periods of economic unbalance, both for individuals and SMEs that are most vulnerable in those times.

\section{b) Complementary Currency System Initiated by Communities}

The Bristol Pound $(f B)$ is a form of local community currency launched in 2012, in the town of Bristol, by Chris Sunderland and 11 co-founding members. In the video, What is the Bristol Pound (2012), Sunderland explains how the objective of this currency is to encourage people to spend their money with local, independent businesses, making sure it sticks to the city of Bristol. The Bristol Pound works in the following way: if you are a business and you accept this currency, you will get more clients that are ready to pay for your services with the Bristol Pound complementary currency. If you are a citizen, you are going to visit more frequently the places that accept this currency. For instance, a business can use their Bristol Pounds to pay a farmer in the local area for fresh fruit and vegetables. This farmer can pay a local architect, who accepts Bristol Pounds for renovating a part of his farm, and so forth. In this way, money keeps on circulating locally to benefit local independent businesses in the area (in the report People powered money, 2015). Payments are possible in the following ways: SMS; electronic payment; APP; and paper money. The exchange rate for this currency is 100 euros $=110$ Bristol Pound, that means you receive more Bristol Pounds for $1 \mathrm{GBP}$ and this ultimately incentivizes its use (in video Bristol Pound - Txt2Pay, 2013). The Bristol Pound currency initiative incorporating digital systems (such as pay-by-text), allows "participating traders to accept electronic payments and

\footnotetext{
1 Definition of Fiat Money by Financial Times: Paper money or coins of little or no intrinsic value in themselves and not convertible into gold or silver, but made legal tender by fiat (order) of the government. Fiat money is an intrinsically worthless object, such as paper money, that is deemed to be money by law. To place it into historical context, one could think of three phases concerning the development of money. Available at: http://lexicon.ft.com/Term?term=fiat-money.
} 
offers customers new, often more convenient ways to purchase goods" (in the report People powered money, 2015, p.56).

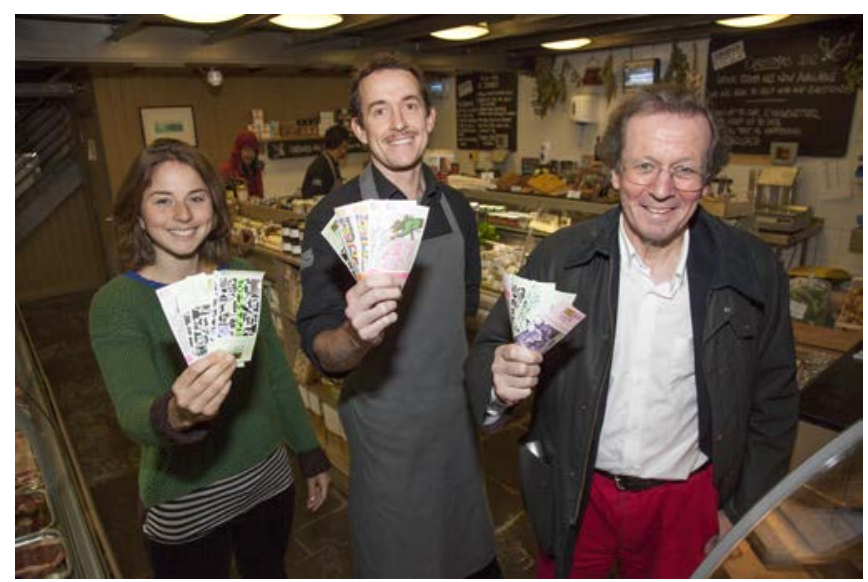

Figure 8. Bristol Pound

There are more than 800 businesses that accept Bristol Pounds and more than thousand users have a Bristol Pound account. If a person spends Bristol Pounds at a local shop, the owner of this shop can spend them again by using the currency to buy supplies from another local business and pay local taxes to the Bristol City Council (in the video, What is the Bristol Pound, 2012). Since about $80 \%$ of the national currency leaves almost immediately, the use of a local currency ensures that circulation remains territorially. This also increases the cash flow between independent businesses and stimulates local employment and sustainable development (Hickey, 2015). It is safe to assume that Schumaher's transition economic theories and movements have provided inspiration and ideas for these types of local economies to thrive. Additionally, Independent businesses are vital for healthy communities as they employ more people. This is also evident through the creation of new enterprises, social and green projects and less pollution, since buying locally means it is not necessary to ship or fly products from far away. Moreover, buying locally decreases emissions through reduced transportation externalities (in the video Why use the Bristol Pound? 2014).

In terms of service typologies, the Bristol Pound case shows it is a closed system format, but this primarily refers to the currency being local and not only stimulating the local economy, but also creating stronger bonds within the community by increasing social capital (similar cases include Brixton Pound and Sardex). The use of this local currency also increases the awareness of the impact of one's economic activity. It has a centralised operation service structure of issuing the currency. Furthermore, Bristol is the first city in the UK in which taxes can be paid in Bristol Pounds. Fortunately, it is not seen as a threat to the national economy by local authorities, but on the contrary as a positive support for local traders since the currencies remains only within this city. Another important point is that account holders can convert pounds to and from pounds sterling and the currency is backed one-one by the national currency. Transactions include both business-to-customer and business-to-business typologies and the Bristol Pound belongs to the public sector.

\section{c) Complementary Currency System Initiated by Government}

Makkie is a time currency system that was initiated by the municipality of Amsterdam, the housing corporations and local residents in 2012, as part of Amsterdam East District. Participants of this reward scheme are encouraged to trade among themselves as well, such as babysitting or administrative help. The purpose of Makkie is to empower local people, to encourage them to take an active role in their community and to improve livability in the neighbourhood (Qoin, n.d.). For example, local residents are rewarded with Makkies when they actively contribute to their neighbourhood that needs additional support with overcoming crime, low-income, unemployment, etc. (CCIA, 2013). Activities for gaining Makkie can include, for example: cleaning public space, doing the housekeeping for an elderly person and/or helping to organize a local event. Makkies can be redeemed for goods and services at local shops and organizations such as: free entrance to the 
cinema, museum, swimming pool, a significant rebate at local independent traders and/or a free subscription at the library (CCIA, 2013). The value of 1 Makkie is equal to 1 hour of work (CCKG, 2013).

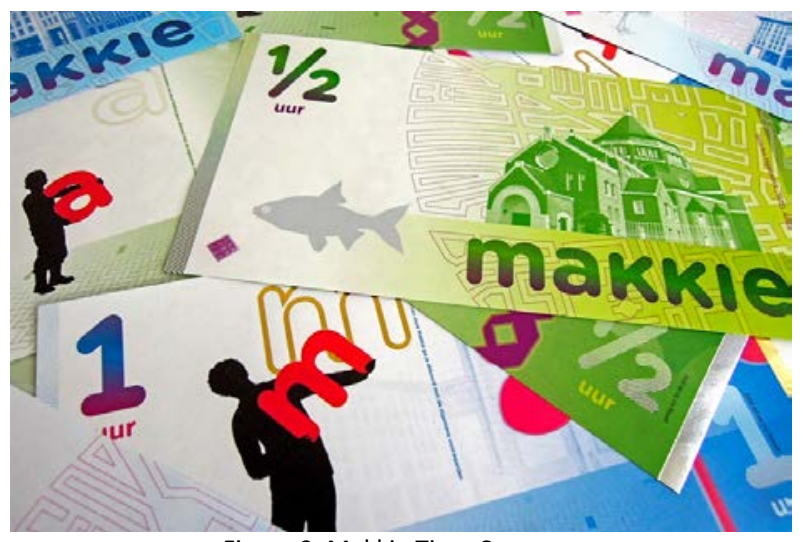

Figure 9. Makkie Time Currency

The management of the municipality has made a plan for Makkies to focuses on (i) youth, (ii) families with multiple problems, (iii) isolated older people, (iv) drug addicts and homeless, and (v) the public space (CCIA, 2013). The municipality has become convinced that it should use innovative tools to make a difference and has therefore decided to work together with Qoin to introduce a community currency program in the neighbourhood (in the video Community Currency 2.0, 2013). The objectives are:

- A clean, green area - aiming to improve the public space;

- A decrease of social isolation - many people who have little contact with their neighbours or local residents (are socially or physically disabled; who are not able to work; who are not integrated into the Western society and do not speak the Dutch language);

- Enhance skills and self-esteem (target unemployed or poorly educated);

- Offering prospects for young people as a way to challenge young people through the use of new local currency;

- Strengthen local entrepreneurs and the link between them and the neighbourhood (CCIA, 2013).

In terms of service typologies, the Makkie case shows it is a closed system format and has a centralized operation service structure. It is a reward scheme, belonging to the public sector and initiated by the local municipality. The transaction typologies include peer-to-peer exchange of new skills, network building, learning from each other, etc. The possibility to earn points can stimulate people to be active again, increasing employment opportunities. Also, the business-to-customer transaction model enables local companies to create jobs and contribute to safety on the streets. Developing linkages between these local companies, businesses and the residents is therefore of vital importance. In this project, entrepreneurs are involved in two ways: they will accept the community currency as a payment for certain products or services. Secondly local companies can provide internships for young people in the neighbourhood to assist in obtaining a basic qualification. The point of interest here is that community currency programs speak to people's abilities, not to their limitations.

\section{Reflections on Developed Economies}

One of the most prominent aspects of complementary currency systems in developed economies, as seen from the cases above, is the establishment of an opposite logic in relation to regular currencies. The general and most common approach to money is to accumulate and potentially save as big an amount as possible. However, the examples illustrate a set of 'demurrage' charged currencies (Eisenstein, 2011) that are designed in such a way to prevent people from hoarding (to accumulate for preservation) money. This can be seen as a strategy to keep interest rates low, prices stable and to encourage individuals to continuously put forward their money back into the economy, especially in time of economic and political uncertainty. Wir Bank demonstrates this point through the positive 
credit balances that do not earn any interest, since holding onto money does not benefit anyone. This also supports the notion that demand for Wir increases in periods of economic unbalance and decreases in periods of growth (Lietaer and Dunne, 2013). Its purpose is to serve as a mutual credit clearing system in currency shortages (Ruddick \& Mariani, 2013). What is even more relevant to this discussion is the fact that no money actually changes hands because in cases such as Wir, currencies are created in the moment of exchange. Wir Bank is a "unique hybrid model of mutual credit and fiat currency where the reimbursement of fiat currencies automatically removes the complementary currency credits out of circulation, avoiding any kind of inflation of value" (Author, 2016. p125).

Time-based currencies, such as Makkie, show a couple of positive points in the generation of social added value. These are marked by reciprocal benefits, rewarded with time-credits as a way to value, be recognized and open up access. This is where 'co-production of service models' is based on active and equal participation and the result is engagement of many rather than the few. Such reward schemes decrease social isolation, enhance skills and self-esteem, stimulating people to be active again.

In the case of Bristol Pound, with the objective to encourage people to think about where their money is going, opens up an engaging discourse. The concept further looks at the reason why citizens are willing to commit to spending it locally. Bristol Pound also introduces a concept of 'localized service models' that nudges people's behavior to support local businesses. The analogy to emission reduction through reduced transportation externalities ensures territorial circulation. This also increases cash flow between independent businesses and stimulates local employment and sustainable development. This active citizenship additionally reduces the carbon footprint and thus contributes to the promotion of sustainable lifestyles.

In conclusion, developed economies develop complementary currency systems in order to accomplish economic benefit, individual or community empowerment, enhancing collaboration and the use of existing local resources.

\section{Lessons Learnt from both Developing and Developed Economies}

Motivations to use new currency models are mostly driven by the fact that individuals, who are socially or economically disadvantaged, are unable to have permanent access to formal banks. Trust, safeguarded by social groups where these individuals belong to, is based on the communal interests of those communities. Contracts are based on trust as opposed to legal documents and ensured by social pressures. Here, reputation is a mechanism to ensure good behavior and to be a fundamental condition for the implementation of complementary currencies.

The main purpose of the explored currency cases is to inject complementary capital. As the word indicates, complementary refers to a parallel form of income circulation (Lietaer, 2001) and does not aim to substitute or to be an alternative to the regular fiat currencies. The cases presented have shown that a lack of local currencies prevents individuals, communities and neighbourhoods from bartering with goods and services they are able to offer. The fundamental driver for economic stability and increase in trade is due to the member's ability to trade their excess capacity (Ruddick, Richards and Bendell, 2015), i.e. their 'personal idle capacity'. The inclusion into a larger circuit opens up participation opportunities, connecting businesses with new customers sharing value (in the report People Powered Money, 2015) and valorising the individual activities and capacities.

Community currencies enable community involvement and make the local governing of these projects more sustainable than regular currencies. The main benefits are that they assist local citizens and businesses, allowing residents to protect, care for and sustain the local environment, by linking unmet needs with unused resources (Lietaer and Hallsmith, 2006).

Local currencies have the potential to keep the currency fixed to that local area, supporting independent traders in order to maintain diversity in business. Using local currencies not only stimulates the local economy but also creates stronger bonds within the community by increasing social capital. The nudging of behavior of citizens to visit more the places that accept local currencies potentially enables the development of novel service business models. These include cooperation 
between local stakeholders and the inclusion of a wide spectrum of new local actors. The behavioural change fostered by the use of local currencies, further affects the development of a social economy, since users of those currencies give preference to products and services found on their local territories. Complementary currencies bring behaviour change through meritocracy and using existing local resources (Author, 2016, p.127). Complementary currencies act as systemic structural components and provide structural solutions to financial exclusion (Lietaer, et al., 2010) by transforming limits into opportunities (Manzini, 2015). This holistic collaborative approach benefits every individual within that system and therefore encourages new forms of economic development i.e. 'consumption without money'. This also stresses equality among citizens through created exchanges and makes these systems sustainable, enabling territorial and social cohesion.

In both economic contexts, complementary currencies have a common aim that is to provide the ability to pay short-term obligations in time of economic crisis. Most of the cases encourage and facilitate a self-help and ethical finance model without interest, founded on the principle of reciprocity and mutual support. They demonstrate that exchanges that build communities without money are possible even on large scale and can be lasting entities. Complementary currencies are seen as a tool, strategy and framework for establishing new service systems that empower people, through the creation of new networks, increasing social ties, local knowledge and expertise.

The synthesis of these cases brings us to the assumption, that the underlying mechanisms of complementary currency systems are the same as with fiat currencies that intend to solve economic problems but are limited in their functionalities. Their lack of access to individuals in need of economic support does not permit the empowering of self-organising communities. On the contrary community currencies increase overall economic and social stability. The purpose functionalities of complementary currency systems can be summarised in the following way:

- $\quad$ Effective tool to bring people actively into the process of solving the needs of their community by themselves;

- Inequality is addressed in a unique way, balancing capacity and resources through reward programs;

- Complementary currencies enable SMEs through networks of commercial circuit to support mutual trade by lending and receiving credit, raising community cohesion and nudging collaborative behaviour;

- Sustainable behaviour is incentivised through credits, implementation of local currencies and environmental awareness.

\section{Service Design and Complementary Currency Systems}

Having looked at the economic and social aspects of complementary currency systems, it is now time to see the relevance of these systems to the service design discipline. In the book Design for Services (Meroni and Sangiorgi, 2011), the authors highlight the distinction in designing for services, as opposed to service design or design of services. This key preposition captures the transformative process where design between people is not final result, but rather the 'action platform' that enables a multiplicity of possible interactions to occur. As seen in the previous case studies, some of them have shown complementary currencies systems creating the conditions to support exchange i.e. providing the conditions through service systems for exchanges to take place in those communities, circuits, etc. Up until now, different systems have always operated on the 'one-way' system of pushing products, services and the organization of people and their interactions (Leadbeater, 2008). However, if a service is a regulated form of co-production of benefits between two or more parties, aiming at solving a certain problem or need (Meroni and Sangiorgi, 2011), then service design has the power to grasp these socio-economic transformations, to "recognize these limits and experiments with ways of transforming them into opportunities" (Manzini, 2015, p.2) and to propose new economic models based on complementary currency systems. 
Currencies have the potential to be re-designed, in order to serve a different purpose and to adapt to an emerging economic paradigm. Since monetary failures all have a structural cause, design strategies focused on a "systemic discontinuity with pre-existing situations" (Manzini in Meroni, 2007, p.13) can reframe problems in order for subversion to take place. What is even more relevant to this discourse are collaborative service models that foster collaborative participations in the design process and in the way products and services are consumed. Therefore, social currencies need to rely on "collaborative services as social services where final users are actively involved and assume the role of service co-designers and co-producers" (Jégou and Manzini, 2008, p.32). In order to foster interactions to occur in the co-creation of value, the role of the designer is to facilitate and act as 'an enabler' within these collaborative platforms (Meroni and Sangiorgi, 2011). Collaborative projects and exchange of services through peer-to-peer platform in turn build communities that increasingly diffuse new systems of value that are altruistic, helpful, resourceful and based on intrinsic reward (Toffler, 1980).

\section{Complementary Currency Systems as Social Innovation}

The growing field of social innovation has not only been a primary debate among academia, but even more broadly, it has become the highlight of business strategies and government policy design. It is important to reflect on the potentials of complementary currency systems as a social innovation. The case studies have highlighted certain elements that allow for the hypothesis that complementary currency systems can be effective tool, service system and strategy to achieve social innovation. The example of social pressure affecting behavior shows the potential for these systems to influence the creation of trust that is based on collaborative principles. Other examples have shown how the complementary currency method brings behavioral changes through reward. We have looked at the different initiation determinants that are evidences of change happening thanks to "individuals, movements or organizations" (Mulgan, et al., 2007). Impressive grassroots movements always emphasize empowerment such as "enabling people to solve their own problems, rather than waiting for the state, or heroic leaders, to solve problems for them" (Mulgan, et al., 2007, p.16). The Bristol Pound is a perfect example of this, having the government accept taxes in the newly created local currency. This is a social innovation in government policy design that serves as an inspiring example of how local governance needs to holistically address socio-economic issues. We have also seen the mechanism of guaranteeing membership encouraging both responsibility and trust within those networks. It is evident that these types of social "innovations are driven more by changes in behavior than by changes in technology or the market and they typically emerge from bottom-up rather topdown processes" (Jégou and Manzini, 2008, p.29).

\section{Conclusion}

The service design discipline provides a framework within which an in-depth analysis of case studies of complementary currency systems is performed. Through the lens of service design, the research explores different economic environments, local communities, motivations for establishing alternative circuits, governance models, service system typologies, etc. The analysis allows us to perceive different complementary currency systems through the perspective of service models that can serve as inspiring solutions for potential alternative economic models to be designed and applied in different contexts. The case studies illustrate the type of collaboration models that have been initiated by individuals, communities and governments in both economic contexts. Each case demonstrates how complementary currency systems provide job opportunities, knowledge exchange and business development in times of crisis. Through this analysis, it becomes clearer how service design can potentially support the transformation of idle capacities between individuals, businesses, etc., into collaboration opportunities through the means of a new currency. The most important aspect of this analysis is to view how a complementary enabling exchange mechanism can be codesigned and how diverse stakeholders can be included into a newly design economic network. 
The paper highlights the structural causes of contemporary social and economic failures, by dissecting the reasons that cause monetary collapses. It gives light to the potential of complementary currency systems as structural solutions to be implemented in diverse economic contexts. Complementary currency systems present different meanings in developing and developed contexts, and each context has different motivations, conditions, and purposes for creating them. Complementary currency systems in developing economies are created for the purpose of establishing financial inclusion, and building stronger community ties and trust. On the other hand, developed economies implement complementary currency systems in order to accomplish economic benefit, individual or community empowerment, enhancing collaboration and the use of existing local resources. Complementary currency systems are a tool for linking unmet needs with unused resources. I am therefore led to believe that small-scale initiatives that are designed, prototyped and implemented in diverse community can become small-scale initiatives as strategies for subversion and intervention. By designing systems of permanent or temporary access to credit to individuals who need it most, but also entrepreneurs, start-up founders, unemployed professionals, active citizens can co-produce and consume services for a mutual benefit. This type of active and equal participation and local empowerment can lead to a 'proactive democracy' based on economic stability, informal financial institution based on trust and behavioural change through reward.

The baseline thinking with the opposite logic to saving money (hoarding), sets the stage for the discussions presented in this research. This opposite thinking of money as a tool and not as an end in itself introduces an entirely new approach to what money is, what it can do and what it can become. This new thinking becomes the role of design to investigate the systemic rules governing social and economic structural components and dynamics of complementary currency systems. This opens up strategic opportunities for designing new social economies, where potentially the future interest of a new service system, the underlying mechanism, and successful operation of exchanges, relies solely on the benefits they can bring to the communities themselves. The potential to design money according to the sense systems present in our community today, shows an incredible advantage in changing the prevailing and existing orders. That is to say that design has the power to change things for the better and since it is possible to redesign how we live, commute, work, etc., towards more sustainable lifestyles, it is also possible to redesign our economies. Service design is deployed within this research, not only by using service design methods for analysis of existing best practices, but also to further explore its potential to lead economic transformations. As a researcher, I am drawn to believe this is the power of service design, to not only respond to contemporary socio-economic conditions, but to also contribute to new ways of practicing democratized economics.

\section{References}

Allen, J., Massey, D., 1988. The Economy in Question. London: Sage Publications.

Armendáriz de Aghion, B., Morduch, J. 2000. Microfinance: Beyond Group Lending. Economics of Transition, 8(2), pp. 401-20.

Author, 2016. PhD Dissertation.

Botsman, R., Rogers, R., 2010. What's Mine Is Yours: The Rise of Collaborative Consumption. New York, NY: Harpers Collins.

Bristol Pound - Txt2Pay, 2013. [video] Bristol: One of the founders of Bristol Pound, viewed $9^{\text {th }}$ November 2016, <http://bristolpound.org/accounts>.

CCIA, 2013. Currency Pilot: Makkie. Amsterdam, Holland: Community Currencies in Action (CCIA). Available at: <http://communitycurrenciesinaction.eu/makkie/> [Accessed 23 November 2016]. 
CCKG, 2013. Makkie. Community Currency Knowledge Gateway (CCKG). Available at: <http://community-currency.info/en/currencies/makkie/> [Accessed 13 December 2016].

Community Currency 2.0, 2013. [video] Interview with Sander de Rijke, viewed on 27 November 2016, < https://www.youtube.com/watch?v=iNCgJUIZGkM>.

Eisenstein, C., 2011. Sacred Economics. Money, Gift \& Society in the Age of Transition. Evolver Editions.

Ghatak, M., Guinnane, T. 1999. The Economics of Lending with Joint Liability: Theory and Practice. Journal of Development Economics, 60(1), pp. 195-228.

Greco, Jr. T.H., 2009. The End of Money and the Future of Civilization. VT, USA: Chelsea Green Publishing Company.

Hickey, S., 2015. The innovators: the Bristol pound is giving sterling a run for its money. The Guardian, [online] 7 June. Available at: < https://www.theguardian.com/business/2015/jun/07/the-innovatorsthe-bristol-pound-is-giving-sterling-a-run-for-its-money>. [Accessed 22 November 2016].

Jha, A.K., 2000. Lending to the Poor: Designs for Credit. Economic and Political Weekly, [ejournal] 35(8/9), pp. 606-609. Available through: Loughborough University Library website http://www.lboro.ac.uk/library/ [Accessed 25 November 2016].

Kalinowski, W., 2011. Currency Pluralism and Economic Stability: The Swiss Experience. [pdf] Veblen Institute for Economic Reforms. Available at:

<http://www.vebleninstitute.org/IMG/pdf/currency_pluralism_and_economic_stability_eng_oct_201 1_.pdf> [Accessed 14 September 2016].

Kennedy, M., Lietaer. B.A., Rogers, J., 2012. The Promise of Regional Currencies. Devon, UK: Triarchy Press.

Lietaer, B.A. 2001. The future of money: A new way to create wealth, work and a wiser world. London: Century.

Lietaer, B.A., Hallsmith, G., 2009. Community Currency Guide. Global Community Initiatives. [pdf] Available at:

<http://andersomgaanmetgeld.be/en/files/nl/documents/publications/community_currency_guide.p df> [Accessed 10 July 2016].

Lietaer, B.A., Ulanowicz, R.E., Goerner, S.J., McLaren, N., 2010. Is Our Monetary Structure a Systemic Cause for Financial Instability? Evidence and Remedies from Nature. Journal of Futures Studies, Special Issue on the Financial Crisis [online] Available at:

http://www.lietaer.com/images/Journal_Future_Studies_final.pdf [Accessed 11 October 2016].

Lietaer, B.A., Arnsperger, C., Goerner, S., Brunnhuber, S., 2012. Money and Sustainability: The Missing Link. Devon, UK: Triarchy Press.

Lietaer, B.A., Dunne, J., 2013. Rethinking money: How new currencies turn scarcity into prosperity. San Franscisco: Berrett-Koehler.

Manzini, E., 2015. Design, when everybody designs: An introduction to design for social innovation. Cambridge, MA: MIT Press.

McKinnon, J., Alston, M., 2016. Ecological Social Work: Towards Sustainability. London, UK: Palgrave. 
New Economics Foundation, 2015. People powered money. Designing, developing and delivering community currencies, London, UK. Available at: < http://community-currency.info/wpcontent/uploads/2015/06/ccia-book-people-powered-money.pdf> Accessed $18^{\text {th }}$ November 2016.

O'Sullivan, A., Sheffrin, S.M., 2003. Economics: Principles in Action. Upper Saddle River, New Jersey: Pearson Prentice Hall.

Qoin, n.d. Makkie. QOIN Money that matters. Available at: <http://www.qoin.com/what-wedo/programmes/makkie/> [Accessed 18 November 2016].

Roodman, D., 2011. Due Diligence: An important inquiry into Microfinance. Washington, D.C.: Center for Global Development.

Ruddick, W.O., 2011. Eco-Pesa: an evaluation of a complementary currency programme in Kenya's informal settlements. International Journal of Community Currency Research, 15(A), 1-12, [online] Available at: https://ijccr.net/2012/05/29/eco-pesa-an-evaluation-of-a-complementary-currencyprogramme-in-kenyas-informal-settlements/ [Accessed 17 November 2016].

Ruddick, W.O., Mariani, L., 2013. Complementary Currencies strengthening the Social and Solidarity Economy: Case studies from Kenya. In: UNRISD (United Nations Non-Governmental Liaison Service), International Conference on "Potential and Limits of Social and Solidarity Economy", session on "Alternative Finance and Complementary Currencies". Geneva, Switzerland, 6-8 ${ }^{\text {th }}$ May 2013.

Ruddick, W., Richards, M. and Bendell, J., 2015. Complementary Currencies for Sustainable Development in Kenya: The Case of the Bangla-Pesa. International Journal of Community Currency Research 19 (Summer) pp.18-30.

Sengupta, R., Aubuchon, C.P., 2008. The Microfinance Revolution: An Overview. [pdf] Federal Reserve Bank of St. Louis Review, January/February 2008, 90(1), pp. 9-30.

Stodder, J., 2009. Complementary credit networks and macroeconomic stability: Switzerland's Wirtschaftsring. Journal of Economic Behavior \& Organization, 72(1), pp.79-95.

Studer, T., 1998. WIR in Unserer volkwirtschaft. Translated by Beard, P.H. 2006. WIR and the Swiss National Economy. [e-book] Basel: WIR. Rohnert Park, CA: Sonoma State University. Available at: <http://www.lulu.com/content/301348> [Accessed 23 October 2016].

Torekes, 2010. How can Torekes be used? [online] Available at: <http://www.torekes.be/en/how-cantorekes-be-used> [Accessed 17 October 2016].

Torekes, 2010. Workflow: Torekes explained [online] Available at: <http://www.torekes.be/en/overtorekes/werkwijze> [Accessed 17 October 2016].

What is the Bristol Pound, 2012 [video] Bristol: Bristol Pound and Real Economy Director (Chris Sunderland), viewed $8^{\text {th }}$ November 2016 , < http://bristolpound.org/what>.

Why use the Bristol Pound, 2014. [video] Bristol: Owen Davis, viewed $9^{\text {th }}$ November 2016, <http://bristolpound.org/whyjoin>.

WIR Magazin, 1994. 60 Years of the WIR Economic Circle Cooperative: Origins and Ideology of the Wirtschaftsring. WIR Magazine. Available at: <http://projects.exeter.ac.uk/RDavies/arian/wir.html> [Accessed 14 December 2016].

Wuthrich, W. 2004. Alternatives to Globalization. Cooperative Principle and Complementary Currency. Current Issues. Translated by Beard, P.H. n.d. Zeit-Fragen. CA: Sonoma State University. Article 1: Topical Questions \#30, August. Available at:

<http://www.zeitfragen.ch/ARCHIV/ZF_119d/T01.HTM> [Accessed 19 November 2016]. 
Yunus, M., 2002. Grameen Bank II: Designed to Open New Possibilities. Grameen Bank, [online] 3 October. Available at: <http://www.grameen-bank.net/designed-to-open-new-possibilities/>.

[Accessed 3 December 2016].

\section{List of Figures}

Figure 1. Service Typologies

By Author

Figure 2. Developing Economies

By Author

Figure 3. Developed Economies

By Author

Figure 4. Grameen Bank

Source:

http://sowestimeast.files.wordpress.com/2010/07

Figure 5. Eco Pesa

Source: 
http://cdn1.pri.org/sites/default/files/story/gallery/Bangla6.JPG

Figure 6. Torekes Currency

Source:

http://www.eurocities2013.eu/admin/upload/torekes_groot.jpg

Figure 7. Wir Bank

Source:

http://oltnerwoche.ch/img/2014/01/bawo_WIR-ON-TOUR-22.jpg

Figure 8. Bristol Pound

Source:

http://www.bristol.gov.uk/sites/default/files/images/council_and_democracy/council_news/Bristol\% 20Pound\%20Markets\%20pic.jpg

Figure 9. Makkie Time Currency

Source:

http://communitycurrenciesinaction.eu/wpcontent/uploads/2014/05/Makkie-again.jpeg 